\title{
Optimal Placement of Distributed Generation System to Improve Power Quality
}

\begin{abstract}
In the large power system, there exist different types of disturbances such as harmonic distortion, voltage Sag, voltage collapse and voltage swell. These disturbances are main causes of poor power quality in the distribution system. Out of which voltage sag is main power quality problem thus it is required to mitigate these problems to have a good power quality. This paper proposes the wind turbine based distributed generator that is designed in MATLAB simulation and detects the optimal placement of distributed generator with reliable size so that the voltage sag is eliminated. The distributed generator is used during overload condition and emergency condition to improves the power quality of the power system.
\end{abstract}

Vinay Anand

Keywords- Distributed generator (DG), voltage sag, voltage swell, voltage collapse.

\section{INTRODUCTION}

With the Growing population and shifting of people from rural areas to metropolis results in rise in demand of electrical energy [1], [2]. The high-power flow from distributing station to customer feeders give rise to various type of disturbance and severe faults that affects the power quality harmfully. Out of all power quality problems, voltage sag is most severe problem that effects the voltage profiles to a very low level. The main causes of voltage sag in the power system is due to the overloading condition that occurs during starting of large number of loads simultaneously. Another reason of voltage sag is that when the power grid supplies electrical power more than its ride through capability then leads to voltage sag resulting in voltage collapse [3], [4]. Consequently, it is necessary to maintain constant and reliable power quality so that the power can be transferred more reliably from distribution system to load without undergoing into voltage sag [5]. The presented paper deals with the improvement of power quality by mitigating voltage sag from the system. There exist different types of methods for the improvement of Voltage Sag such as Thyristor controlled reactor (TCR), Distribution Static compensator (DSTATCOM), Dynamic Voltage Restorer (DVR) and Distribution Generation (DG) [6], [7].

In the proposed paper, to eliminate the power quality problem and to reduce the voltage sag problem due to overloading, a Distribution Generator is placed in an optimal location to provide a continuous power supply in case of overloading condition as well as during peak load condition. This Distribution Generator must be placed near the load centre to supply the power with less power losses. The installation of Distribution Generation system promotes the use of renewable energy resources due to high energy

Revised Manuscript Received on 14 September, 2019.

Vinay Anand, Department of Electrical Engineering, Sanskriti University, U.P., India.(Email: sanpubip@gmail.com) demand and protection of environment from the pollution [8]. The Voltage sag is most severe problems of power system that affects the durability of power system equipment. The following non-conventional energy resources can be used in distribution generation system such as solar photovoltaic panel (PV panel), Diesel Engine, Wind Turbine Generation and fuel cell [9].

\section{PLACEMENT OF DG AT SUITABLE LOCATION}

"Distribution Generator is a modern technology based electric power generator that is based on green energy concept" [5],[10] . The use of distribution generator is done by keeping in mind that it should not affects the environment and should be sustainable. The size of distribution Generator is very small and is used to fulfil the energy demand during the peak time or overloading condition. Therefore, it is required to place the DG at a particular position near the load centres to supply more power to the load without undergoing into voltage sag and losses [11].

There are basically two types of sources used as a distribution generation system which are characterize below;

I. Non-conventional energy sources:

1) Solar Photovoltaic panel (PV)

2) Wind Turbines

3) Storage battery

4) Ocean thermal energy source

5) Geothermal energy source

6) Biomass energy source

II. Conventional Energy sources:

1) Fuel cell

2) Diesel Generator 


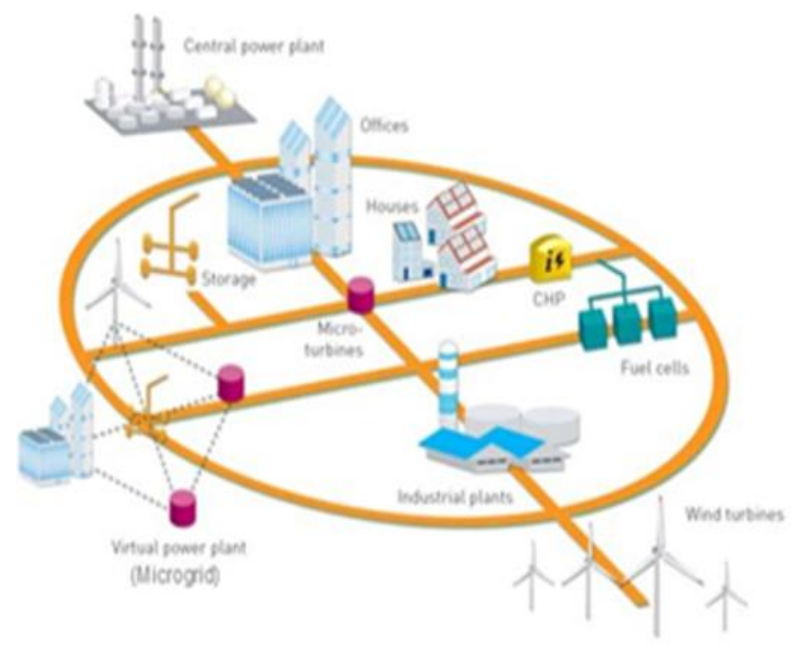

Fig. 1: DG in radial system

The size of DG is much lesser than the total amount of load and total losses. Usually, the scope of Distribution Generator lies among $15 \%$ to $41 \%$ of total amount of losses and load [12]. Besides some advantages the DG has some disadvantages such as with the increment of voltage profile in the distribution line it may increase the fault occurrence

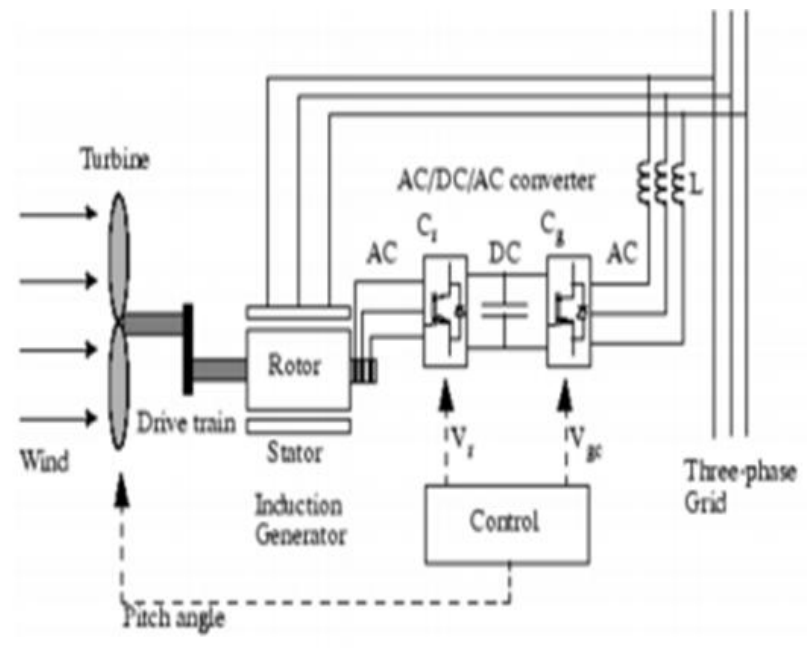

Fig. 2 Wind Turbine and DFIG System

In this proposed system, the wind turbine with doubly fed induction generator is used as a Distribution Generation System. It reduces the voltage sag condition by supplying additional electricity. The furthermost thing that has to be consider is the location of DG that is to be placed at an appropriate place for reducing the voltage sag from the system. The size of DG is also important factor that determines the improvement in power quality. If the size of DG increases then the voltage profile also increases but on increment of the size in distribution generator, the transmission losses also increases. Therefore, the place where the voltage sag is minimum, at that place the distributed generator is installed. Fig. 2 represents the wind turbine and DFIG system connected to the electric grid acting as a distributing generator for providing additional power during voltage sag condition or in case of voltage collapse. possibility.

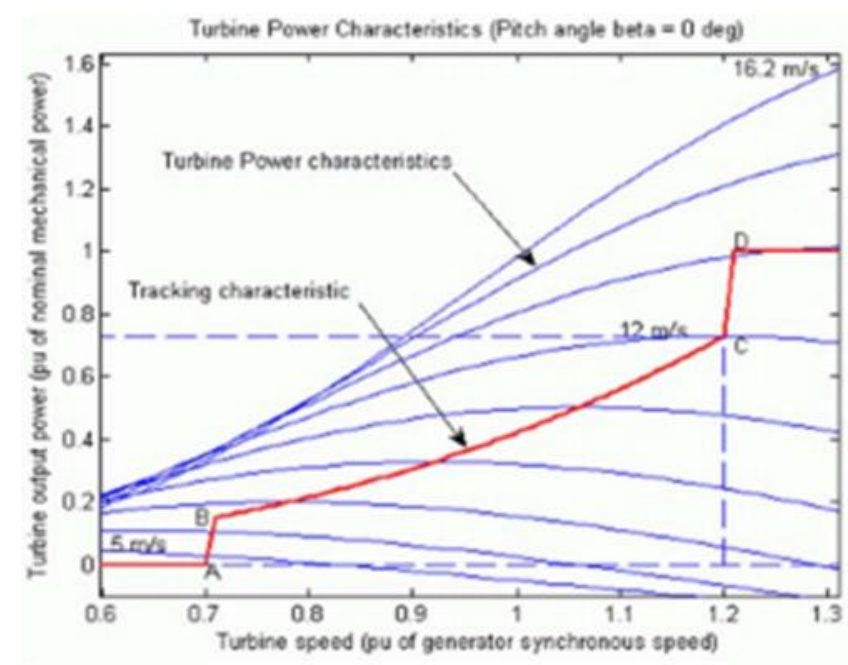

Fig.3 Characteristics of Wind Turbine

\section{RESULTS}

The single line diagram of the radial distribution system with 11 bus is shown in fig.4. this distribution system consists of 11 bus and table.1(a) represents data bus along with its length, resistance and reactance of line in $\mathrm{km}$. table 1(b) shows load data in which flow of active power $(\mathrm{kw})$ and reactive power (Kvar) is determined.

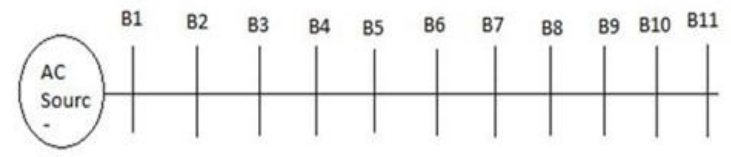

Fg.4 11 Bus Radial system

Table 1(a). Data Bus

\begin{tabular}{|l|l|l|l|l|}
\hline \multicolumn{2}{|l|}{ BUS } & Length in $\mathbf{K m}$ & $\mathbf{R}$ in ohm/KM & $\mathbf{X}$ in ohm/KM \\
\hline 0 & 1 & 0.450 & 0.124 & 0.106 \\
\hline 1 & 2 & 0.150 & 0.330 & 0.350 \\
\hline 2 & 3 & 0.200 & 0.330 & 0.350 \\
\hline 3 & 4 & 0.025 & 0.330 & 0.350 \\
\hline 4 & 5 & 0.250 & 0.330 & 0.350 \\
\hline 5 & 6 & 0.100 & 0.330 & 0.350 \\
\hline 6 & 7 & 0.075 & 0.330 & 0.350 \\
\hline 7 & 8 & 0.050 & 0.330 & 0.350 \\
\hline 8 & 9 & 0.100 & 0.330 & 0.350 \\
\hline 9 & 10 & 0.035 & 0.330 & 0.350 \\
\hline 10 & 11 & 0.150 & 0.330 & 0.350 \\
\hline
\end{tabular}

Table 1(b). Load Data

\begin{tabular}{|l|l|l|}
\hline BUS & Active Power (KW) & Reactive Power (KVAR) \\
\hline 1 & 0.000 & 0.000 \\
\hline 2 & 178.711 & 149.504 \\
\hline 3 & 178.711 & 149.504 \\
\hline 4 & 0.000 & 0.000 \\
\hline 5 & 178.711 & 149.504 \\
\hline 6 & 178.711 & 149.504 \\
\hline 7 & 178.711 & 149.504 \\
\hline 8 & 178.711 & 149.504 \\
\hline 9 & 178.711 & 149.504 \\
\hline 10 & 178.711 & 149.504 \\
\hline 11 & 178.711 & 149.504 \\
\hline
\end{tabular}

3.2 Analysis of The Voltage Profile of the 11 Bus System:

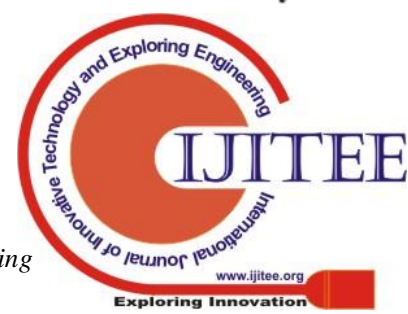


The distribution generator (DG) wind turbine is connected at bus no. 11 and the whole model is design in the MATLAB simulation software. When the three line to ground fault occurs at the bus 11 the magnitude of voltage is reduced and occurs voltage sag in the system. Fig.5 shows the disturbance in the voltage profile due to the voltage sag caused by three line to ground fault. In this condition no DG is connected at the bus and the voltage profile is reduced to very low.

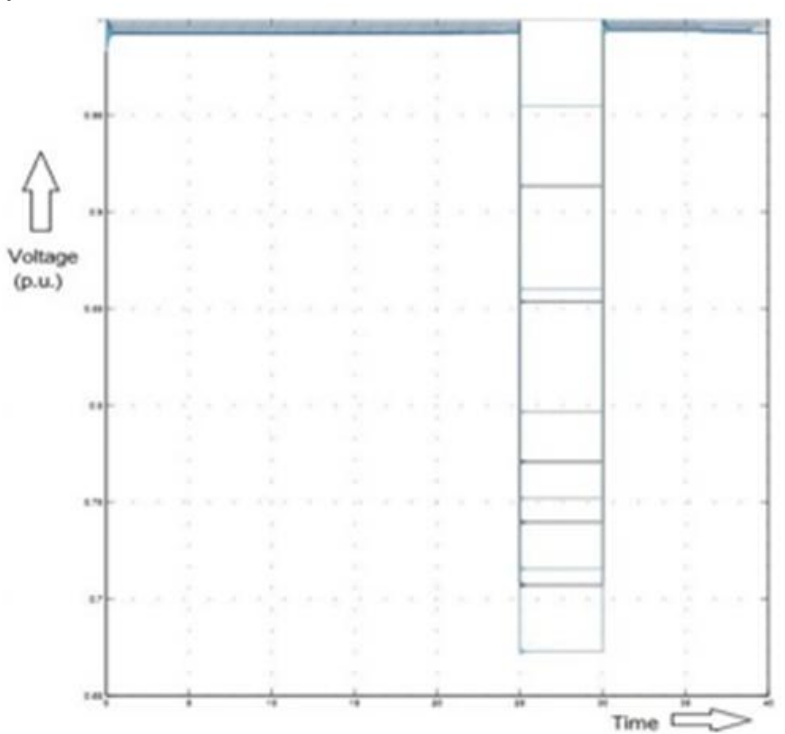

Fig 5. Three LG Fault without DG

Table. 2 represents the different buses voltage magnitude during the fault condition with distribution generation. During the application of distribution generator at bus number 11 the voltage is rised suddenly and the voltage swell condition occurs. The voltage swell with DG at bus 11 is shown in fig.6.

Table 2: Voltage Magnitude for FAULT AT BUSll WITH DG

\begin{tabular}{|l|c|c|c|c|c|c|c|}
\hline $\begin{array}{c}\text { Bus } \\
\text { no. }\end{array}$ & $\begin{array}{c}\text { Without } \\
\text { DG at }\end{array}$ & \begin{tabular}{rl|l|l|} 
DG at \\
Busll
\end{tabular} & $\begin{array}{c}\text { DG at } \\
\text { Bus10 } 0\end{array}$ & $\begin{array}{c}\text { DG at } \\
\text { Bus9 }\end{array}$ & $\begin{array}{c}\text { DG at } \\
\text { Bus8 } 8\end{array}$ & $\begin{array}{r}\text { DG at } \\
\text { Bus7 }\end{array}$ & $\begin{array}{c}\text { DG at } \\
\text { Bus6 }\end{array}$ \\
\hline 1 & 0.9546 & 0.9546 & 0.9546 & 0.9547 & 0.9547 & 0.9547 & 0.9547 \\
\hline 2 & 0.9132 & 0.9134 & 0.9134 & 0.9135 & 0.9135 & 0.9135 & 0.9135 \\
\hline 3 & 0.8597 & 0.8600 & 0.8600 & 0.8601 & 0.8601 & 0.8601 & 0.8602 \\
\hline 4 & 0.8531 & 0.8534 & 0.8534 & 0.8535 & 0.8536 & 0.8360 & 0.8537 \\
\hline 5 & 0.7963 & 0.7965 & 0.7966 & 0.7966 & 0.7967 & 0.7967 & 0.7968 \\
\hline 6 & 0.7704 & 0.7707 & 0.7708 & 0.7708 & 0.7709 & 0.7710 & 0.7710 \\
\hline 7 & 0.7514 & 0.7517 & 0.7519 & 0.7519 & 0.7520 & 0.7521 & 0.7520 \\
\hline 8 & 0.7146 & 0.7151 & 0.7153 & 0.7153 & 0.7153 & 0.7153 & 0.7152 \\
\hline 9 & 0.7146 & 0.7151 & 0.7153 & 0.7153 & 0.7153 & 0.7153 & 0.7152 \\
\hline 10 & 0.7063 & 0.7068 & 0.7070 & 0.7070 & 0.7069 & 0.7069 & 0.7069 \\
\hline 11 & 0.6717 & 0.6725 & 0.6724 & 0.6724 & 0.6723 & 0.6723 & 0.6723 \\
\hline
\end{tabular}

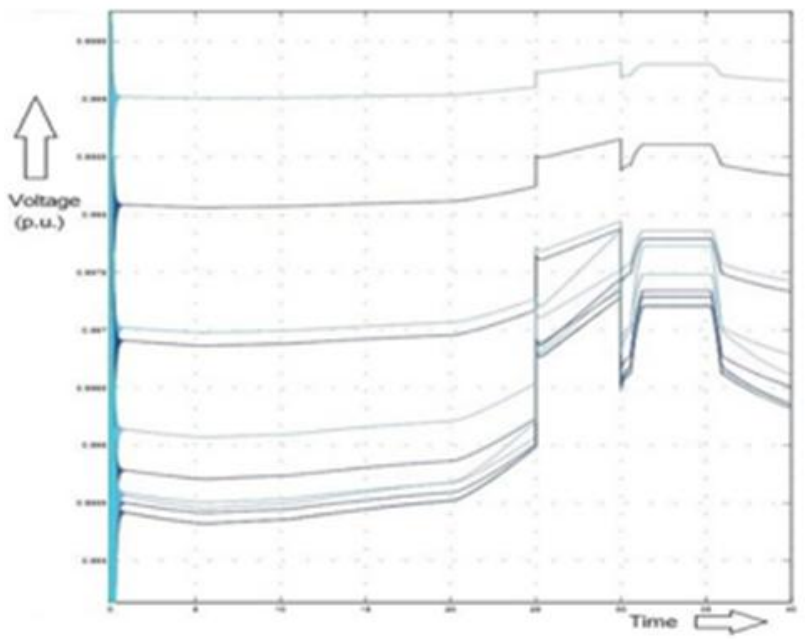

Fig. 6. Voltage Swell with DG at bus no.11

\section{CONCLUSION}

In this paper the wind turbine based Distributed Generator (DG) is designed in the MATLAB simulation software and the optimal selection of size and location of distributed generator is done for mitigating the voltage sag from the system. After placing DG at suitable place, the effect of voltage swell in the system is shown in fig.6. three line to ground fault is generated in the simulation software for the purpose of analyses of effect of voltage profile without DG and with DG. The radial distribution system that is studied in this paper is consist of 11 bus and the main aim of this paper is to provide an appropriate location of DG so that minimum voltage sag is observed.

\section{REFERENCES}

1. A. K. Panda and N. Patnaik, "Management of reactive power sharing \& power quality improvement with SRFPAC based UPQC under unbalanced source voltage condition,” Int. J. Electr. Power Energy Syst., 2017.

2. M. F. AlHajri and M. E. El-Hawary, "Improving the voltage profiles of distribution networks using multiple distribution generation sources," in LESCOPE'07 - 2007 Large Engineering Systems Conference on Power Engineering, 2007.

3. B. Polajžer, G. Štumberger, S. Seme, and D. Dolinar, "Detection of voltage sag sources based on instantaneous voltage and current vectors and orthogonal Clarke's transformation," IET Gener. Transm. Distrib., 2008.

4. A. Dehghani-Arani and R. Maddahi, "Introduction a multi-objective function in unbalanced and unsymmetrical distribution networks for optimal placement and sizing of distributed generation units using NSGA-II," 2015.

5. D. Q. Hung and N. Mithulananthan, "Multiple distributed generator placement in primary distribution networks for loss reduction,' IEEE Trans. Ind. Electron., 2013.

6. X.-P. Zhang, C. Rehtanz, and B. Pal, "FACTS-Devices and Applications," 2012.

7. S. K. Pandey, S. R. Mohanty, and N. Kishor, "A literature survey on load-frequency control for conventional and distribution generation power systems," Renewable and Sustainable Energy Reviews. 2013. 
8. D. Kumar, S. R. Samantaray, I. Kamwa, and N. C. Sahoo, "Reliability-constrained Based Optimal Placement and Sizing of Multiple Distributed Generators in Power Distribution Network Using Cat Swarm Optimization,” Electr. Power Components Syst., 2014.

9. I. Pisica, C. Bulac, and M. Eremia, "Optimal distributed generation location and sizing using genetic algorithms," in 2009 15th International Conference on Intelligent System Applications to Power Systems, ISAP '09, 2009.

10. F. L. Lewis, Z. Qu, A. Davoudi, and A. Bidram, "Secondary control of microgrids based on distributed cooperative control of multi-agent systems," IET Gener. Transm. Distrib., 2013.

11. R. Viral and D. K. Khatod, "Optimal planning of distributed generation systems in distribution system: A review," Renewable and Sustainable Energy Reviews. 2012.

12. F. S. Abu-Mouti and M. E. El-Hawary, "Optimal distributed generation allocation and sizing in distribution systems via artificial bee colony algorithm," IEEE Trans. Power Deliv., 2011. 